\title{
The spatial epidemiology of asthma: a chronic non- communicable disease and a neglected epidemic
}

\author{
Mungrue Kameel ${ }^{*}$ and Sanford Steve \\ ${ }^{*}$ Correspondence: kameel.mungrue@sta.uwi.edu

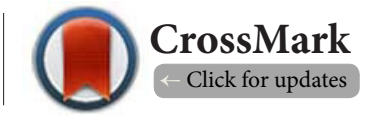

Faculty of Medical Sciences, The University of the West Indies, Trinidad and Tobago.

\begin{abstract}
Objectives: The aim of this study was to measure the occurrence of acute exacerbations of asthma at an Emergency Health Facility for the period 2010-12, and to describe its spatial distribution using ARC GIS 10.0 (ESRI).

Design: The study design is an observational cross sectional study in which cases of acute exacerbations of asthma treated at an Emergency Department of a semi rural 24hr health facility were reviewed. The address of each patient was geocoded and mapped.
\end{abstract}

Setting: An emergency health facility offering $24 \times 7$ service.

Participants: All patients who met the criteria for an acute exacerbation of asthma during the period 201012.

Main outcome measures: The occurrence and geographic distribution of asthma presenting for rescue therapy.

Results: The number of cases of acute exacerbations asthma increased in each consecutive year. Spatially, while the geographical distribution of cases was diffuse we identified a cluster (Valencia). Using spatial overlay there was a correlation with temperature and humidity.

Conclusions: Over the three year period 2010-2012 there was an increase in the occurrence of acute exacerbations of asthmatic requiring emergency care, emphasizing that Asthma is still an important Public Health challenge.

Keywords: Asthma, GIS, emergency admissions, trends

\section{Introduction}

It is estimated that about 300 million individuals of all ages and ethnic backgrounds live with asthma. This number is expected to increase to 400 million by 2025, which will increase the burden of providing care worldwide [1]. In the United States (US) asthma accounts for $25 \%$ of the 2 million visits to emergency rooms [2]. Asthma also accounts for more than 10 million outpatient visits and 500,000 hospitalizations in the US yearly [2]. In Barbados between 1970-1990 admissions to an acute setting increased from 36 to 360 patients per month despite an increase of only $10 \%$ in the island's population during that time [3]. Similarly for the one year period 1999 in Trinidad 5.3\% of all adult admissions and $23 \%$ of pediatric admission to the emergency room were asthma related [4]. As a result acute asthma impacts significantly on emergency facilities. Thus morbidity continues to be high despite effective treatments
[5]. Consensus guidelines consistently highlight the aim and objectives of treatment: (1) to eliminate or minimize asthma symptoms, (2) to achieve the best possible lung function and (3) to prevent asthma exacerbations, the latter being the primary focus of this study $[6,7]$.

According to the Global Initiative for Asthma (GINA), [8] asthma is defined as a chronic inflammatory disorder of the airways resulting in hyper-responsiveness, bronchial constriction and excessive mucus formation. The clinical diagnosis is based on the clinical presentation and investigation [6], which may include lung function tests and chest radiograph to sputum cell counts (total and differential) [9], and fraction of nitric oxide in exhaled breath [10].

Asthma may be classified according to the age of onset into childhood or adult or according to nature of severity of symptoms (acute/chronic). Childhood asthma is a complex phenomenon, 
Kameel et al. Journal of Allergy and Asthma 2014,

particularly in distinguishing episodes of wheeze triggered by a viral infection from asthmatic children in which symptoms are initiated by several triggers including allergen exposure, irritant exposure and exercise [11]. It is more common than adultonset asthma. According to a report by the National Center for Health Statistics in the US in 2002, asthma prevalence among children ages $0-17$ years old was 83 per 1,000 as compared to adults in which the prevalence was 68 per 1000 [12].

There are many reports of an environmental and spatial relationship in respect to the incidence of asthma $[13,14]$. A review of the literature reveal no studies on the spatial distribution of asthma in Trinidad hence this is the first study of its kind in Trinidad and Tobago.

The aims of this study are to measure the occurrence of acute exacerbations of asthma at a major health facility in the eastern half of the island for the period 2010-12 and consequently describe the spatial distribution of acute exacerbations of asthma in North East Trinidad using ArcGIS (ESRI) 10.0.

\section{Methods}

We used an incident case study design. Incidence is defined as the number of new cases of asthma that occur in a given period of time as compared to recurrent acute asthma [15]. The incidence of first and new episodes of asthma in patients presenting to the health facility were studied. The population consisted of all patients admitted to a health facility with a diagnosis of acute asthma in a defined geographical area. We aimed to collect all patients. For the purpose of this study an acute exacerbation of asthma was defined by the following criteria: (1) any patient who presented to the emergency room (ER) with cough, dyspnea, and wheezing, (2) a history of asthma, (3) clinical signs of asthma, (4) laboratory investigations including a chest X-ray, (5) physician's diagnosis and (5) received rescue therapy for asthma. In addition we defined childhood asthma as all patient 0-17 years who met the above criteria. Adult asthma was classified as all patients who met the above criteria and were 18 years and over [10]. The only exclusion criteria were chronic bronchitis and emphysema, the two most common chronic obstructive airway diseases in Trinidad and Tobago.

All patients who met the above criteria were selected for entry into the study. The medical records of these patients were reviewed and the following data were extracted, age, gender, address, drugs administered, time of admission and PEFR. The PEFR was measured using a Wright's Peak Flow meter. The process involved first a description of the different steps in PEFR measurement to the patient. These included: connecting a clean mouthpiece, ensuring the marker is set to zero, stand up or sit upright, take as deep a breath in as you can and hold it, place the mouthpiece in your mouth and form as tight a seal as possible around it with your lips, breathe out as hard as you can, observe and record the reading. The process was repeated 3 times and the highest reading was recorded.

Data were collected on humidity, air quality, rainfall, tem- perature, barometric pressure, soil type and vegetation from meteorological monitoring stations located in North-East Trinidad, as well as, census data from the Town and Country planning division, Forestry division and the Faculty of Land \& Survey Department of the UWI.

In Trinidad, the universal transverse Mercator system is used to create conformal projections, meaning that angles and small shapes on the globe project as the same angles or shapes on a 2-dimension map. When necessary field measurements using a Global Positioning System (GPS) were used to determine specific coordinates of the location of residence of patients. The software ArcGIS 10.0 (ESRI) was used for georeferencing and to perform the required spatial analysis. ArcGIS is a system for working with maps and geographic information developed by Environmental Systems Research Institute, Inc. (Esri), for which the University of the West Indies is a licensed user.

Themes were generated using all available data. Spatial overlays were performed by layering one theme over the other, to identify any existing correlation between incidence and study factors. The mean center identifies the geographic center (or the center of concentration) for a set of features, calculated as. The mean center is given as:

$$
\bar{X}=\frac{\sum_{i=1}^{n} x_{i}}{n}, \bar{Y}=\frac{\sum_{i=1}^{n} y_{i}}{n}
$$

where $x_{i}$ and $y_{i}$ are the coordinates for feature $i$, and $\mathrm{n}$ is equal to the total number of features.

The Weighted Mean Center extends to the following:

$$
\bar{X}_{w}=\frac{\sum_{i=1}^{n} w_{i} x_{i}}{\sum_{i=1}^{n} w_{i}}, \bar{Y}_{w}=\frac{\sum_{i=1}^{n} w_{i} y_{i}}{\sum_{i=1}^{n} w_{i}}
$$

where $w_{i}$ is the weight at feature $i$.

The tool also calculates the center for a $3^{\text {rd }}$ dimension if a $z$ attribute exists for each feature:

$$
\bar{Z}=\frac{\sum_{i=1}^{n} z_{i}}{n}, \bar{Z}_{w}=\frac{\sum_{i=1}^{n} w_{i} z_{i}}{\sum_{i=1}^{n} w_{i}}
$$

The mean center is the average $\mathrm{x}$ - and $\mathrm{y}$-coordinate of all the features in the study area. It's useful for tracking changes in the distribution or for comparing the distributions of different types of features.

Further analysis included, buffering, queries, clip, point and polygon as functional spatial statistics. In addition linear regression was performed using SPSS v12. The ethics committee of the University of the West Indies approved the protocol for the study.

\section{Results}

A total 5976 patients meet our criteria for childhood and adult asthma (acute exacerbation) and were eligible for entry into 
Kameel et al. Journal of Allergy and Asthma 2014,

the study. Although no patient was excluded in some patients not all of the required data were available. We recorded data for each of the following years 2010, 2011 and 2012 from a major emergency centre in a semi-rural setting in East Trinidad. The total number of admissions and the number of admission for acute exacerbation increased during 2010 to 2012, (Table 1). There was no real difference in the number of childhood cases to adult cases. However the occurrence of asthma in adult females for every year was almost double that seen among girls.

Table 1. The distribution of the occurrence of asthma by age and gender for 2010, 2011, and 2012.

\begin{tabular}{|c|c|c|c|}
\hline $\begin{array}{l}\text { Asthma } \\
\text { occurrence }\end{array}$ & 2010 & 2011 & 2012 \\
\hline $\begin{array}{l}\text { Total number of } \\
\text { admissions (all } \\
\text { cause) to the AED }\end{array}$ & 37,566 & 43,494 & 45,582 \\
\hline $\begin{array}{l}\text { Number of acute } \\
\text { exacerbations of } \\
\text { asthma }\end{array}$ & 1235 & 2131 & 2610 \\
\hline $\begin{array}{l}\text { Proportion of all } \\
\text { admissions } \\
\text { attributed to } \\
\text { asthma }\end{array}$ & $3.29 \%$ & $4.89 \%$ & $5.76 \%$ \\
\hline $\begin{array}{l}\text { Change in } \\
\text { number and } \\
\text { proportion of } \\
\text { admissions from } \\
2010\end{array}$ & -- & $896(72.6 \%)$ & $1375(111 \%)$ \\
\hline $\begin{array}{l}\text { Total number of } \\
\text { cases } \\
<18 \text { years }\end{array}$ & $530(44.33 \%)$ & $886(41.7 \%)$ & $1150(43.43 \%)$ \\
\hline $\begin{array}{l}\text { Total number of } \\
\text { cases } \geq 18\end{array}$ & $690(55.77 \%)$ & $1242(58.3 \%)$ & $1442(56.57 \%)$ \\
\hline Males & $602(48.28 \%)$ & $1092(48.66 \%)$ & $1280(49.16 \%)$ \\
\hline Males $<18$ years & 304 & 551 & 720 \\
\hline Males $\geq 18$ years & 288 & 483 & 557 \\
\hline Females & $633(51.72 \%)$ & $1034(51.34 \%)$ & $1325(50.84 \%)$ \\
\hline Females $<18$ years & 225 & 334 & 430 \\
\hline Females $\geq 18$ years & 402 & 752 & 892 \\
\hline
\end{tabular}

Between 2010 and 2011 there was an increase of 896 cases or a $72.6 \%$ increase in cases from 2010, between 2010 and 2012 there was an increase of 1375 cases or $111 \%$ increase. Also between 2011 and 2012 there were 479 (22.5\%) more cases than 2011.

There appears to be a seasonal pattern of distribution of acute asthma with peaks occurring in May-August corresponding to the rainy season and troughs occurring in the dry season February to April, Figure 1.

Analysis of the point data revealed that for the years 2010, 2011 and 2012 the pattern of admissions of acute exacerbation of asthma was diffuse, Figure 2.

The majority of the cases were distributed in populated areas. However a cluster was also observed in the community of Valencia with 27, 54 and 52 cases originating from this area for the years 2010, 2011 and 2012 respectively. The attack rate for this period was 3 per 1000, 7 per 1000 and 6 per 1000 for each of the 3 years respectively 2010, 2011 and 2012. A buffer analysis was performed which showed that 156, 273 and 254 cases were recorded within one (1) kilometer of the health facility for each of the years 2010, 2011 and 2012 respectively. The spatial data was interpreted further using centrographic statistics. The mean center was calculated for 2010, 2011 and 2012 and the standard deviation about the mean center was calculated for each month of each year, Table 2.

The central deviance was used to construct a region of confidence in which $75 \%$ of the occurrences are contained. Due to the diffuse distribution encountered a skewed 75 percentile in the year 2011 was observed, Figure 2. This constructed region of $75 \%$ confidence identified communities (from Tacarigua to Valencia). This is true for all years except 2011, whose constructed region encompasses an area much larger than that proposed. Nevertheless $25 \%$ of all cases admitted to the emergency center or each of the years 2010, 2011 and 2012 came from outside this region.

Additional statistical analysis was conducted in an attempt to ascertain a link between the meteorological data and the occurrence of an acute exacerbation of asthma using Pearson's correlation coefficient. While there was a significant association between asthma occurrence and temperature in $2010(p=0.044)$ and $2012(p=0.048)$ there was no significant association in 2011 $(p=0.52)$. However there was a stronger association of asthma occurrence and humidity (2010, $\mathrm{p}=0.042,2011 \mathrm{p}=0.049$, and $2012, p=0.048$ ). Likewise there was similar association with barometric pressure $(2010, p=0.054,2011, p=0.019,2012$, $\mathrm{p}=0.048)$ and rainfall $(2010, \mathrm{p}=0.048,2011, \mathrm{p}=0.58$, and 2012, $\mathrm{p}=0.040$ ).

\section{Discussion}

One of the major findings of this study is the $111 \%$ increase in the number of admission to the ER for acute exacerbations of asthma i.e., from 1235 in 2010 to 2610 in 2012 . Although total admissions (all causes) increased, the proportion attributed to acute exacerbations of asthma also increased from $3.29 \%$ to $5.80 \%$ during the study period. These are important findings as it provides evidence of the increasing burden of asthma. These findings concur with current global trends of an increase in the prevalence of asthma. Yet our findings are less than those reported by Monteil et al., in 1999 from the largest hospital on the island i.e., the Port of Spain General hospital located in the capital city [4]. This is not unusual, as previous studies have indicated that the occurrence of asthma is greater in urban areas as compared to rural regions [5]. Although the hygiene hypothesis has not been widely studied in the Caribbean this finding may supports the concept as the rural environment has 
Kameel et al. Journal of Allergy and Asthma 2014,
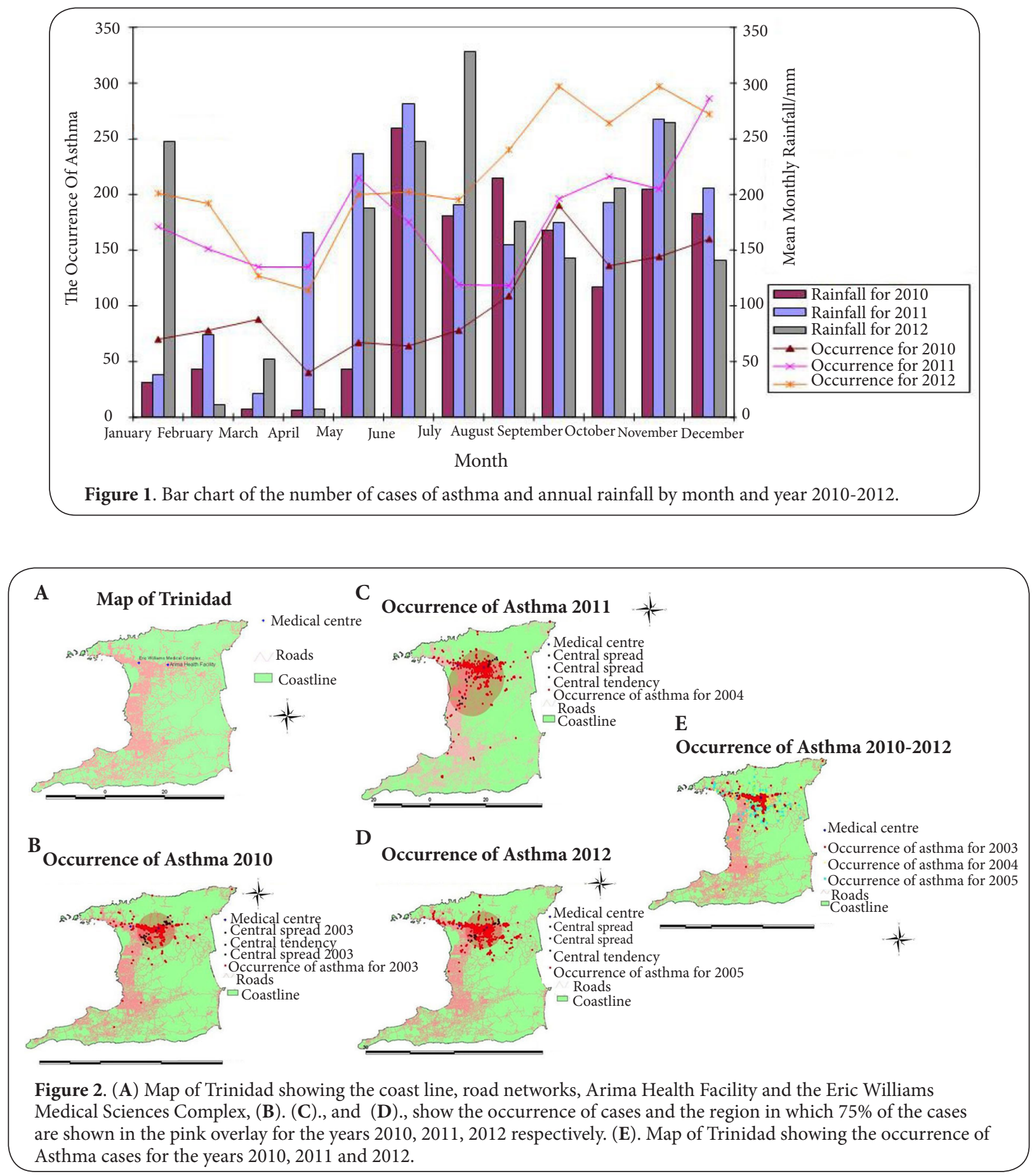

been described to act as a protective factor in the development of allergic diseases $[16,17]$. However, they contradict findings from studies in inner-city homes in the USA [18].

Although more females presented with acute exacerbations the difference was not significant $(p>0.05)$ and the overall ratio of females to males was close to 1:1. GINA has recorded higher prevalence rates in females over males [5]. However there were twice as many cases of adult females presenting with acute exacerbations of asthma compared to girls $\leq 18$ years. Adult-onset asthma develops after age 20. Adult-onset asthma may be triggered by allergies or may be non-allergic phenomena. In fact non-allergic phenomena are the main contributors to adult-onset asthma, and include hormonal changes associated with pregnancy and menopause, which, in part contributes to higher prevalence rates of asthma in females compared with males. Wasilevich et al., in 2000-2002 
Kameel et al. Journal of Allergy and Asthma 2014,

Table 2 . Mean centre by year.

\begin{tabular}{lllllllll}
\hline 2010 & X_COORD & Y_COORD & 2011 & X_COORD & Y_COORD & 2012 & X_COORD & Y_COORD \\
\hline January & 686985.69342 & 1175268.98364 & January & 686095.92812 & 1174771.18114 & January & 686577.63345 & 1174647.99736 \\
February & 685648.79340 & 1174714.47139 & February & 686095.92812 & 1174771.18114 & February & 686209.52007 & 1174136.12435 \\
March & 686306.62965 & 1173929.45563 & March & 685889.01082 & 1174799.19284 & March & 685660.57048 & 1174961.24897 \\
April & 685608.55367 & 1174026.64802 & April & 680924.95381 & 1166158.15644 & April & 684740.32025 & 1174721.01774 \\
May & 685890.27160 & 1175326.61117 & May & 682113.27913 & 1168541.26662 & May & 686250.21860 & 1174586.00000 \\
June & 685753.90454 & 1174928.87279 & June & 681611.52856 & 1168370.20172 & June & 686090.04871 & 1174977.28584 \\
July & 686318.88932 & 1175541.19497 & July & 685574.38629 & 1175163.05173 & July & 685279.58650 & 1174903.00351 \\
August & 685682.67912 & 1174920.56699 & August & 685278.05004 & 1174974.77900 & August & 686383.33713 & 1174973.10486 \\
September & 685958.35972 & 1174842.67166 & September & 682602.03098 & 1169017.55816 & September & 686348.70266 & 1174752.97163 \\
October & 685264.95567 & 1174830.50915 & October & 682553.68133 & 1168298.89997 & October & 686288.62240 & 1174911.53914 \\
November & 685555.06971 & 1174748.33108 & November & 682266.37508 & 1168834.33274 & November & 686291.60231 & 1174432.43940 \\
December & 685185.40371 & 1174812.56430 & December & 683493.80382 & 1169612.40455 & December & 685674.65486 & 1174193.74482 \\
\hline
\end{tabular}

showed that the average number of hospitalizations per year for males was 6329 and that of females was 8986 [19]. Further two thirds of asthma patients have onset in childhood (as young as 4) and only one third develop symptoms after age 20 [20]. Changes in circulating hormones during puberty and menopause have been linked to greater susceptibility [6]. Remissions are also more likely to occur in young children often referred to as transient wheeze [20]. In infants tested shortly after birth those who subsequently developed asthma have lung function levels that are not significantly lower than those of their peers [21]. It is reasonable to conclude that the asthmatic lung is most often acquired during preschool years and that aggressively treating symptomatic young children at high risk for asthma with inhaled corticosteroids could blunt or reverse it natural history [22]. Hence the implications of our findings are: (1) more girls are likely to develop chronic asthma as adults, (2) the detection and optimal treatment of asthma in girls may be lacking, (3) there is a different biological mechanism mediating asthma progression in this group or (4) according to the hygiene hypothesis girls are less exposed than boys and therefore more prone to chronic asthma.

In our setting $43.1 \%$ of asthma admissions to the ER were children. This is higher than in developed countries for example the United States where $34.6 \%$ of asthma patients admitted to hospital were children [23]. This finding must be interpreted cautiously as it could be explained simply by differences in population. However it is consistent with global trends of an increase in childhood cases of asthma [6], emphasizing the need for early detection, optimal management and follow up to prevent progression to chronic asthma.

The diffuse pattern revealed by the spatial analysis of the occurrence of asthma suggests that health facilities particularly in developing countries are providing services to a wider range of communities than intended. This is because facilities are publicly funded by Ministries of Health with a policy that no patient should be turned away as occurs in Trinidad. The major implication of this finding is for policy planning, in terms of capacity and delivery of a sustainable service for both acute care but especially long term follow up to prevent progression of the disease. Therefore, in a small island states like Trinidad, delineated boundaries cannot be used to validate the type of needs assessment. Spatially, it was observed that most cases occurred within a $5 \mathrm{Km}$ buffer of the health facility. This finding is consistent with the literature which provides evidence that more developed communities have a higher prevalence of asthma [5]. Several factors may be contributing to this finding including easy accessibility to a facility as well as the impact of environmental factors in developed communities. Another important finding of the spatial analysis was the identification of a cluster of cases in Valencia, which presents an opportunity for further investigation.

Analysis of the meteorological data showed a pattern of increase in the number of cases of asthma during the months of June to December (the wet season). There was an increase in the level of rainfall during that period each year, and statistical analysis revealed for 2011 a significant positive correlation. We argue that global warming may be an influencing factor, which may be responsible for the increase observed in the number of cases of acute exacerbations of asthma each year during the wet season. Global warming is defined as a gradual warming of the Earth's atmosphere due to the burning of fossil fuels and industrial pollutants and is responsible for changes in global climate patterns. These changes include the rise in sea levels, the change in the amount and pattern of precipitation and can lead to an can lead to the increase frequency and intensity of floods, droughts, heat waves and hurricanes. While there is a paucity of published data on the seasonal variation in asthma occurrence in the Caribbean, Spence and colleagues as far back as 1964-66 showed that respiratory syncytial virus (RSV) outbreaks in Trinidad began in 
Kameel et al. Journal of Allergy and Asthma 2014,

the respective months of June, September and August which is in the peak of the rainy season [24]. Mathews et al., reported a strong correlation between RSV and asthma especially in the age group $\leq 4$ years and detected RSV exclusively in the rainy season (June-December) [25]. In addition associations between thunderstorms, which occur predominantly in the rainy season and asthma morbidity, have been identified in multiple locations around the world $[\mathbf{2 6}, \mathbf{2 7}]$. The most prominent hypotheses for thunderstorm-related asthma are linked to bio-aerosols and involve the role of rainwater in promoting the release of respirable particulate matter [26,27]. Further during the rain season here is a greater frequency and intensity of floods and cyclones resulting in an increase in fungal spore production, a powerful asthma and rhinitis trigger [28]. The link between mold and asthma and rhinitis is well known and has been established through exposure to dampness and moisture in indoor environments [29]. Ault reported that increasing temperatures encourage the growth of mould and fungi (found more often in the wet season) and stimulate photochemical smog, all of which contribute to respiratory distress [30].

The major limitation to the study was the difficulty to collect all available data for each patient. This was mainly due to incomplete records, lack of a standard write up of records, as well as the illegibility of the writing proved a challenge to data collection. All medical records are paper records. This study was further limited as the meteorological data obtained was approximated for the whole country and not localized to the regions investigated during the course of this study, however the land mass is relatively small as the island is approximately 60 miles long and 30 miles wide. Some data sets such as air quality indexing which may have enhanced the nature of the study were not available.

\section{Conclusion}

We provide evidence that asthma is an important global-health priority alongside, and complementary to, the other current global initiatives. It requires large investments in surveillance and research to promote quality-assured asthma drugs affordable and accessible to all, along with development and enhancement of health services for long-term management and regular follow-up.

\section{Competing interests}

The authors declare that they have no competing interests.

Authors' contributions

\begin{tabular}{|l|c|c|}
\hline Authors' contributions & MK & SS \\
\hline Research concept and design & $\checkmark$ & -- \\
\hline Collection and/or assembly of data & $\checkmark$ & $\checkmark$ \\
\hline Data analysis and interpretation & $\checkmark$ & $\checkmark$ \\
\hline Writing the article & $\checkmark$ & -- \\
\hline Critical revision of the article & $\checkmark$ & $\checkmark$ \\
\hline Final approval of article & $\checkmark$ & $\checkmark$ \\
\hline Statistical analysis & $\checkmark$ & -- \\
\hline
\end{tabular}

Acknowledgement

We wish to acknowledge the Department of Land and Surveys, Faculty of Engineering University of the West Indies for sharing data for the creation of all maps.

\section{Publication history}

Editors: Donald Cockcroft, University of Saskatchewan, Canada. Thomas John Brett, Washington University School of Medicine, USA.

Received: 17-Aug-2014 Final Revised: 29-Oct-2014

Accepted: 13-Nov-2014 Published: 20-Nov-2014

\section{References}

1. Masoli M, Fabian D, Holt S and Beasley R. Global Burden of Asthma 2004. I Website

2. Asthma and Allergy Foundation of America. Asthma Facts and Figures. 2006. I Website

3. Naidu RP. Use of the logbook in a quality assurance exercise in the hospital emergency department in Barbados. West Indian Med J. 1990; 39:44. | Article

4. Monteil MA, Joseph G, Changkit C, Wheeler G and Antoine RM. Comparison of prevalence and severity of asthma among adolescents in the Caribbean islands of Trinidad and Tobago: results of a nationwide cross-sectional survey. BMC Public Health. 2005; 5:96. | Article | PubMed Abstract | PubMed Full Text

5. Lalloo UG, Bateman ED, Feldman C, Bardin PG, Plit M, Irusen EM and $\mathrm{O}^{\prime} B$ rien J. Guideline for the management of chronic asthma in adults--2000 update. South African Pulmonology Society Adult Asthma Working Group. S Afr Med J. 2000; 90:540-1. | Article | PubMed

6. Global Initiative for Asthma (GINA). Global Strategy for Asthma Management and Prevention. 2005. I Website

7. Lemiere C, Bai T, Balter M, Bayliff C, Becker A, Boulet LP, Bowie D, Cartier A, Cave A, Chapman K and Cowie R et al. Adult Asthma Consensus Guidelines update 2003. Can Respir J. 2004; 11 Suppl A:9A-18A. PubMed

8. Global Initiative for Asthma (GINA). Pocket Guide for Asthma Management and Prevention. 2005. I Website

9. Djukanovic R, Sterk PJ, Fahy JV and Hargreave FE. Standardised methodology of sputum induction and processing. Eur Respir J Suppl. 2002; 37:1s-2s. | Article | PubMed

10. American Thoracic Society, European Respiratory Society. ATS/ERS recommendations for standardized procedure for the online and office measurements of exhaled lower expiratory nitric oxide and nasal nitric oxide. Am J Respir Crit Care Med. 2005; 171:191-30. I Pdf

11. Williams $\mathrm{H}$ and McNicol KN. Prevalence, natural history, and relationship of wheezy bronchitis and asthma in children. An epidemiological study. Br Med J. 1969; 4:321-5. I Article I PubMed Abstract I PubMed Full Text

12. National Center for Health Statistics. Asthma Prevalence, Health care use and Mortality. 2002. | Website

13. Monteil MA. Asthma in the English-speaking Caribbean. West Indian Med J. 1998; 47:125-8. | Article | PubMed

14. Worldwide variation in prevalence of symptoms of asthma, allergic rhinoconjunctivitis, and atopic eczema: ISAAC. The International Study of Asthma and Allergies in Childhood (ISAAC) Steering Committee. Lancet. 1998; 351:1225-32. | Article | PubMed

15. von Mutius $E$ and Radon K. Living on a farm: impact on asthma induction and clinical course. Immunol Allergy Clin North Am. 2008; 28:631-47. | Article | PubMed

16. von Mutius E. 99th Dahlem conference on infection, inflammation and chronic inflammatory disorders: farm lifestyles and the hygiene hypothesis. Clin Exp Immunol. 2010; 160:130-5. | Article I PubMed Abstract | PubMed Full Text

17. Platts-Mills TA, Erwin E, Heymann P and Woodfolk J. Is the hygiene hypothesis still a viable explanation for the increased prevalence of asthma? Allergy. 2005; 60 Suppl 79:25-31. | Article | PubMed 
Kameel et al. Journal of Allergy and Asthma 2014,

http://www.hoajonline.com/journals/pdf/2054-9873-1-2.pdf

18. Matsui EC, Hansel NN, McCormack MC, Rusher R, Breysse PN and Diette $\mathrm{GB}$. Asthma in the inner city and the indoor environment. Immunol Allergy Clin North Am. 2008; 28:665-86. I Article I PubMed

19. Wasilevich E and Lyon-Callo S. Epidemiology of Asthma in Michigan: 2004 Surveillance Report. 2004. I Pdf

20. Mahabir D, Pooran S, Motilal H, Ishmael M, Hinds N and Gulliford MC. Acute severe asthma in Trinidad and Tobago. Int J Tuberc Lung Dis. 1999; 3:198-201. I Article I PubMed

21. Martinez FD. Development of wheezing disorders and asthma in preschool children. Pediatrics. 2002; 109:362-7. I Article I PubMed

22. Morgan WJ, Stern DA, Sherrill DL, Guerra S, Holberg CJ, Guilbert TW, Taussig LM, Wright AL and Martinez FD. Outcome of asthma and wheezing in the first 6 years of life: follow-up through adolescence. $\mathrm{Am}$ J Respir Crit Care Med. 2005; 172:1253-8. | Article | PubMed Abstract | PubMed Full Text

23. Akinbami LJ, Moorman JE, Garbe PL and Sondik EJ. Status of childhood asthma in the United States, 1980-2007. Pediatrics. 2009; 123 Suppl 3:S131-45. I Article I PubMed

24. Spence $L$ and Barratt N. Respiratory syncytial virus associated with acute respiratory infections in Trinidadian patients. Am J Epidemiol. 1968; 88:257-66. I Article I PubMed

25. Matthew J, Pinto Pereira LM, Pappas TE, Swenson CA, Grindle KA, Roberg KA, Lemanske RF, Lee WM and Gern JE. Distribution and seasonality of rhinovirus and other respiratory viruses in a cross-section of asthmatic children in Trinidad, West Indies. Ital J Pediatr. 2009; 35:16. | Article PubMed Abstract | PubMed Full Text

26. D'Amato $G$, Cecchi $L$ and Liccardi G. Thunderstorm-related asthma: not only grass pollen and spores. J Allergy Clin Immunol. 2008; 121:537-8. Article I PubMed

27. D’Amato G, Cecchi L and Annesi-Maesano I. A trans-disciplinary overview of case reports of thunderstorm-related asthma outbreaks and relapse. Eur Respir Rev. 2012; 21:82-7. | Article | PubMed

28. Schiermeier Q. Climate and weather: Extreme measures. Nature. 2011; 477:148-9. | Article | PubMed

29. Mendell MJ, Mirer AG, Cheung K, Tong M and Douwes J. Respiratory and allergic health effects of dampness, mold, and dampness-related agents: a review of the epidemiologic evidence. Environ Health Perspect. 2011; 119:748-56. | Article I PubMed Abstract I PubMed Full Text

30. Ault A. Report blames global warming for rising asthma. Lancet. 2004; 363:1532. | Article | PubMed

\section{Citation:}

Kameel $\mathrm{M}$ and Steve S. The spatial epidemiology of asthma: a chronic non-communicable disease and a neglected epidemic. J Allergy Asthma. 2014; 1:2. http://dx.doi.org/10.7243/2054-9873-1-2 